British Association in 1833, a group of enthusiasts formed, somewhat irregularly, a new statistical section. The presence of Quetelet had something to do with its formation, and the new section was recognised by those in authority, although it can scarcely be said to have received their blessing. The president, Adam Sedgwick, delivered himself of some good advice in the rotund style of the day, informing the culprits that because of the irregular circumstances of its formation he would not read the report of this "self-formed Section", and reminding his hearers that "the things with which the Association had to do were the laws and properties of matter and with those alone". Statistical inquiries might be admitted so long as they dealt with "matters of fact, with mere abstractions and with numerical results.... These inquiries, however ...touched the mainsprings of passion and feeling. . . they blended themselves with the generalizations of political science; but when they entered on these higher generalizations that moment they were dissevered from the objects of the Association and must be abandoned by it if it meant not to desert the secure ground which it had now taken. . . . The daemon of Discord would find his way into their Eden of Philosophy."

As the historians of the Society remark, there was more to the same effect. It is small wonder that the Statistical Section resolved that "a more permanent body was necessary to carry out the views and wishes of the Section and it was agreed to establish a Statistical Society in London". Hence arose that public meeting of "Noblemen and Gentlemen" at 21 Regent Street, on March 15, 1834, which marked the beginning of the long and honourable career of what is now known as the Royal Statistical Society.

The annals of its development, as recounted in the scholarly pages of the centenary volume, are absorbing, if unexciting. The progress of the Society is traced with admirable clarity from these modest beginnings to a stage at which, amid a host of other activities, it is playing an important part in forwarding the application of statistical methods to various problems of industry, and the accounts of the work of those eminent statisticians who have cherished the interests of the Society in the past are associated with pleasant little sketches of their personalities which add a living interest to the picture. Perhaps the one trivial criticism, if criticism it may be termed, which can be brought against a wholly delightful volume, is that there are scarcely enough of these touches. We could wish that a president of the Statistical Society could be found who should say of a dull paper, as the venerable Dalton announced in an audible undertone from the rostrum of the Manchester Literary and Philosophical Society, "Well, this is a varra interesting paper for those that take any interest in it".

The Council of the Society, and the distinguished authors of the centenary volume, Dr. Bonar and Mr. Macrosty, are to be congratulated on the issue of a volume that must form a norm for all future writers faced with a similar task.

\section{Allan Ferguson.}

\title{
Science and State Regulation of the Sea Fisheries
}

$\mathrm{O}^{\mathrm{N}}$ September 22, 1863, a Royal Commission commenced inquiries into the Sea Fisheries of the United Kingdom of Great Britain and Ireland. Prof. T. H. Huxley and his fellow commissioners visited eighty-six places, examining methods of fishing in use and interrogating witnesses. Their Report, published in 1866, was a masterly summary of the situation, embodying courageous recommendations in accordance with a declared legislative principle. The first recommendation was as follows:

"We advise that all Acts of Parliament which profess to regulate, or restrict, the modes of fishing pursued in the open sea be repealed; and that unrestricted freedom of fishing be permitted hereafter."

And the principle:

". . . that (apart from the restrictions prescribed by international law, or by special treaties) the produce of the Sea is the property of the people in common; and that methods of fishing are fitting subjects for legislation, only so far as such legislation can be shown to be necessary to secure the greatest possible advantage to the whole nation from the Sea Fisheries; either by suppressing wasteful and uselessly destructive modes of fishing; or by removing legislative obstacles in the way of improved modes of fishing; or by preserving peace and order among fishermen."

Broadly speaking, the great deep-sea fisheries of the present day have been developed under that "unrestricted freedom of fishing" advocated by the 1863 Commission, without let or hindrance in the form of national or international regulation. The passing into law of the Sea-Fishing Industry Act of 1933, therefore, by granting State control over fishing operations, marked the end of nearly seventy years of free fishing by British vessels in the high seas.

By this Act, the British Government has acquired powers to regulate and restrict the fishing of British vessels whereby fishing grounds, times of fishing, fishing gear, quantities of fish to be landed and their quality-all of these being matters over 
which the fishermen formerly exercised freedom of action-are brought under State prescription. Landings of foreign-caught fish are also regulated. Furthermore, by the same Act, the Sea-Fish Commission for the United Kingdom came into being, to investigate and advise the Government as to whether any, and if so, what, steps ought to be taken for reorganising any branch of the nation's sea-fishing industry. One of the first services of this Commission has been to present a Report on the Herring Industry ${ }^{1}$, recommending the establishment of a Herring Board having farreaching powers.

Now it cannot be denied that the Sea-Fishing Industry Act was passed, primarily, to rehabilitate an industry most grievously hit by the general economic depression, but it would be a profound mistake to adjudge the Act solely as a measure to meet business exigencies. Indeed, there appears no escape from the conclusion that, unless the fundamental legislative principle laid down by the Royal Commission of 1863 has been put aside, the Act is nothing less than an indictment of the fishing industry for its "wasteful and uselessly destructive modes of fishing".

In this connexion, the findings of the International Council for the Exploration of the Sea during the meetings held at Copenhagen in June last, are of outstanding significance. Delegates and experts from Belgium, Denmark, Finland, France, Germany, Great Britain, Holland, Norway, Poland, Portugal and Sweden, arrived at fifteen conclusions which were accepted and adopted, with slight amendments, by the Council on June 9 . Nine of these conclusions, as they appear in the (amended) Authentic Text ${ }^{2}$, are given below :

(1) It is important, for the maintenance of the stock, that measures to prevent waste be taken by all countries fishing in the waters included in the Council's investigations.

(2) The most useful measure of control will take the form of prevention, as far as possible, of the capture of young fish below the size at which they can be sold at a remunerative price for the food of man.

(3) It has been shown that, in the case of the trawl net and Danish seine, appreciable protection of young round-fishes can be secured by regulating the size of mesh of the bag or cod-end. This method needs to be further elaborated, but enough experience has been gained to justify a minimum size of mesh which should be required in the construction of the bag or cod-end employed in the open sea.

(4) The minimum mesh which the Council recommends is that already enforced by the regulations of the British Government, which, they are satisfied, will ensure the release of an appreciable quantity of undersized fish now captured and retained.

(5) No way at present practicable of regulating the mesh has yet been devised which would secure the release of flat-fishes up to the sizes at which they ought to be protected and would not release marketable round fish.
(6) It is, therefore, desirable that size-limits should be imposed for flat-fishes in order to discourage fishing on grounds where small flat-fishes form the greater part of the population.

(7) The imposition of size-limits is also desirable for round-fishes, in order to re-inforce the meshregulations, and to remove the temptation for fishermen to evade these regulations when ar sea.

(12) The Council recommends the adoption by all countries, as soon as possible, of size-limits not less than those required by British regulations. It is of the opinion that experience will show that some of these might be usefully extended, and that size-limits might also be introduced with advantage for other fishes, especially cod. It wishes, however, to emphasize the fact that the chief thing to aim at is the prevention of the capture of undersized fish, and that accordingly the regulation of fishing should take first place.

(13) The Council recognizes the difficulty of enforcing different measures of protection for different areas and different fisheries; but it considers that, when the question of increasing the minimum measures now proposed arises, this question will have to be faced and solved.

From these conclusions of competent scientific representatives of all the leading fishing nations of Europe, it would surely seem that the Sea-Fishing Industry Act was not only right in its indictment of wasteful fishing, but also in the methods by which it sought to check this waste. It is especially gratifying, therefore, that the trawling industry has so cheerfully co-operated with the Fishery Departments of the Government to secure the smooth working of the Orders already imposed under the Act, despite the fact that the fishermen of other nations, working the same fishing grounds, have remained free from such regulation. This very circumstance may well prove to be one of the strongest factors in inducing the Governments of Europe to follow the British lead towards the maintenance of fish-stocks at an adequate level, and to ensure that they are utilised in the most economic manner.

Finally, it should not be lost to view that the vitally important conclusions of the International Council were based on knowledge derived from thirty-two years of scientific investigation in which the nations have co-operated. With the fisheries brought under legislative control, the need for scientific surveillance will be greater than ever, not only to perfect the means of protection against wasteful fishing, but also to preserve the fisheries from that purely obstructive legislation which Huxley so fearlessly and rightly condemned.

$$
\text { E. F. }
$$

Sea-Fish Commission for the United Kingdom. First Report The Herring Industry. (Cmd. 4677.) Pp. 51. (London: H.M. StationThe Herring Industry, (Cm

ery 2 Conseil Permanent International pour l'Exploration de la Mer. Rapports et procès-verbaux des réunions, Vol. $90:$ Size-Limits for Rapports et proces-verbaux des reunions, Vol. 90 : Size-Limits for
Fish and Regulations of the Meshes of Fishing Nets. Pp. Xv+61. (CoFish and Regulations of the Meshes of Fishing Nets. Pp.
penhague : Andr. Fred. Host et fls 1934.) $3.00 \mathrm{kr}$. 